\title{
Digital business models and company growth opportunities in the energy market
}

\author{
Boris Kovalenko ${ }^{1 *}$, Elena Kovalenko ${ }^{2}$, Tamara Yakovleva ${ }^{1}$ \\ ${ }^{1}$ Institute of Economics and Management, Herzen State Pedagogical University, Moika str. 48, \\ 191186 Saint Petersburg, Russian Federation \\ 2“ComplexSnab” Co Ltd., Vedeneeva str. 12, 195427 Saint Petersburg, Russian Federation
}

\begin{abstract}
We are currently witnessing significant changes in the global energy market. The energy industry is entering the stage of the 4th energy transition, which is characterized by an increasingly large-scale increase in the use of renewable energy sources and a decrease in the share of fossil fuels. The energy sector is also strongly influenced by the trend of digital transformation and the use of digital technologies. The aim of the work is to study the possibility and conditions of using digital business models by companies in the energy sector to improve competitiveness and market growth. To achieve the goal of the study, the following tasks were set: to analyze the main trends and the state of digitalization of the energy industry; analyze digital business models and assess the possibilities of their use by energy companies; to formulate approaches to transforming the activities of energy companies in the transition to a digital business model. The authors hypothesized that the use of digital business models will allow energy companies to remain competitive and gain access to new markets by introducing new technologies. To conduct the study, the methods of microeconomic and industry analysis, systemic and comparative analysis, and analysis of the organizational behavior of the company were used. The results of the analysis showed that the global energy market is characterized by growth in dynamics and volatility. In order to adapt to changing conditions and maintain competitiveness, energy companies need to take advantage of digitalization and shape a digital strategy. One of the basic elements of an organization's digital strategy is a successful digital business model. The article discusses the types and features of digital business models, and also formulates approaches to transforming the activities of energy companies in the transition to a digital business model.
\end{abstract}

\section{Introduction}

Currently, digital technologies (social, mobile, analytical, cloud, Internet of things, etc.) are penetrating all spheres of society [1]. Artificial intelligence and robots are changing the look of industries $[2,3]$ and the way organizations operate. The digitalization processes are

\footnotetext{
*Corresponding author: kovalenkoboris2015@gmail.com
} 
actively developing in the energy industry. Digitization enables companies to expand technical capabilities to improve customer engagement and satisfaction, streamline business processes, and increase employee engagement [4- 6].

The results of the activities of companies in different industries show that for business differentiation, it is necessary to provide customers not only with better quality or lower prices, but to a greater extent offer a better business model. Thus, in order to succeed in the competitive struggle, companies radically change their business models [7]. The purpose of the article is to analyze digital business models that companies use to increase competitiveness in the market and identify approaches to transforming the activities of energy companies in the transition to a digital business model.

\section{Digital technologies and the energy market}

The energy market is increasingly influenced by factors such as the decarbonization of the world economy, such as the response to climate change and global warming; distributed generation; implementation of projects aimed at energy saving and energy efficiency growth; an increase in the number of electric vehicles; use of energy storage systems (batteries and fuel cells) [8-12].

Thus, according to Navigation Research, Bloomberg Energy Finance [4], more than 200 MW of new generating capacities were commissioned in the world in 2017. If we consider the structure, then almost equal amounts of centralized generation and distributed generation capacities were introduced. Distributed generation is expected to reach more than $250 \mathrm{MW}$ by 2025 , while centralized generation will be even lower than the 2017 level (less than 100 MW).

The energy sector is also strongly influenced by the trend associated with digital transformation and the use of digital technologies (cloud, big data, mobile, Internet of things, artificial intelligence, etc.) in the economy. Energy companies are already actively using digital technologies to automate all stages of the value chain (Table 1).

Table 1. Digital solutions used in energy companies to automate the value chain [5]

\begin{tabular}{|c|c|}
\hline Digital solutions & $\begin{array}{c}\text { Use in energy } \\
\text { companies }\end{array}$ \\
\hline $\begin{array}{c}\text { Drones and industrial } \\
\text { robots }\end{array}$ & $\begin{array}{c}\text { Southern Company, } \\
\text { Swissgrid, Snam, RTE }\end{array}$ \\
\hline AI and predictive analytics & $\begin{array}{c}\text { DUNE ENERGY, PG\&E, } \\
\text { Exelon, TATA POWER }\end{array}$ \\
\hline $\begin{array}{c}\text { Using chatbots for } \\
\text { customer service }\end{array}$ & $\begin{array}{c}\text { Exelon, E.ON, Göteborg } \\
\text { Energi }\end{array}$ \\
\hline $\begin{array}{c}\text { Customer profiling based } \\
\text { on BigData }\end{array}$ & $\begin{array}{c}\text { Innogy, HydroOttawa, } \\
\text { LondonHydro }\end{array}$ \\
\hline
\end{tabular}

The total volume of the global market for digital technologies in the energy sector in 2017 amounted to $\$ 52$ billion. The market is expected to grow to $\$ 64$ billion by 2025 . Areas of automation include maintenance of power plants, installation and operation of "smart" meters, automation of distribution networks, operation of home energy management systems, ensuring the stability of the operation of energy facilities, etc. [4].

The analysis shows that digital technologies are already successfully used in the energy sector to automate tasks for managing the current operating activities of enterprises: asset management, maintenance and repair, procurement, billing and other basic business processes [6]. 
In addition, digitalization contributes to the development of new energy technologies, such as distributed integration, and makes it possible to coordinate the work of complex energy systems.

According to Kearney [13], there is a trend towards decentralizing the value chain of energy enterprises and expanding the list of services that they can offer to consumers. Personalization of customer service and provision of services together with partners from other industries is considered as a strategic goal.

To successfully adapt to the ongoing changes, as well as to use the opportunities provided by digitalization, it is advisable for companies to form a corporate strategy that allows them to offer new customer value that meets or anticipates customer expectations. In this case, it becomes necessary to adjust the current business model and transform it into a digital business model.

\section{Features of digital business models}

There is a plethora of definitions of the concept of "business model". We will use the definition formulated by Osterwalder and Pigne [14] that a business model serves to describe the basic principles of the creation, development and successful operation of an organization.

The results of the analysis show that business models generated by digital technologies can be classified according to different criteria. Consider some of these criteria and their associated business models. There is an approach that involves two possible types of business models: a customer acquisition model or a digital decision model [7].

The business model of attraction involves a comprehensive, individualized approach that ensures customer loyalty. This business model focuses on building trust and customer loyalty in order to achieve high brand loyalty. The implementation of this model involves multichannel interaction with customers, a deep understanding of their needs and rapid response to changes in these needs (Kaiser Permanente). The business model of digital solutions is since customers are provided with products or services with the addition of information, thereby creating a new value.

This business model means the integrated nature of the products and services that are offered to customers in order to meet their needs. Moreover, the strategy is aimed at gradually moving away from the sale of individual products to more complex products with additional value (Shindler Group, Apple). The successful implementation of such a business model requires a digital operating platform that combines all corporate functions in a single unit. The goal is to ensure access for all corporate units to a single database of customers in order to increase their satisfaction and loyalty. In addition, the presence of a corporate culture loyal to digital transformation is important.

Following a dynamic approach, when any kind of business model can be the starting position for the company, and the other kind can be a guideline, we can consider the following typologies of business models. For example, Weill and Woerner [15] offer an approach based on changing the business model in two directions: i) movement in the direction from control in the value chain to participation in the ecosystem; and ii) movement from low customer awareness to full knowledge (purchase history, goals, etc.). As a result of the intersection of these areas, four digital business models can be distinguished:

1. Supplier (P\&G, Vanguard, Chubb Group):

- Implementation of the product through intermediaries;

- $\quad$ Low impact on the end user; 
- $\quad$ Corporate competencies are based on cost reduction and gradual innovation.

2. Modular manufacturer (PayPal, Apple Pay, Square):

- $\quad$ Products / services ready for use;

- $\quad$ The ability to connect to any platform;

- $\quad$ Corporate competencies require continuous innovation for market leadership.

3.Omnichannelity (Nordstrom, Walmart, Citibank):

- Wide multi-product and multi-channel interaction with customers in accordance with their life cycles;

- Close relationship with the end user;

- Integrated value chains.

4. Ecosystem driver (Amazon, Microsoft, WeChat, Fidelity):

- The destination point of the ecosystem;

- $\quad$ Search for suppliers and competing products to satisfy customers;

- $\quad$ Use of customer data from all points of contact;

- $\quad$ Provide an excellent customer experience;

- Implement a rental approach.

According to the approach proposed by Linz et al. [16], two megatrends are currently influencing the activities of organizations - digitalization and service orientation - a servicesoriented. Digitalization enhances the technical capabilities of firms to develop, produce, deliver their proposals and manage large-scale interactions with customers, the servicesoriented approach represents a fundamental change in the field of value proposition for customers towards the joint creation of value and individualization.

The influence of the aforementioned mega-trends guides the decision-making process on choosing a business model in two dimensions: transaction coverage and proposal customization.

Moving along measurement data shows the capabilities that a company can use to develop or modify a business model. Following along the axis - transaction coverage shows the movement of the company from single and independent transactions (single products) to complex and interconnected transactions (related products) with repeated transactions.

Proposal customization is the movement from standardized, batch and automated offers to individualized, created jointly by the company and the client.

Table 2. Types of Digital Business Models [16]

\begin{tabular}{|c|c|c|}
\hline $\begin{array}{c}\text { Transaction } \\
\text { Coverage - High }\end{array}$ & $\begin{array}{c}\text { Platform } \\
\text { Oriented } \\
\text { Business Model }\end{array}$ & $\begin{array}{c}\text { Solution } \\
\text { Oriented } \\
\text { Business Model }\end{array}$ \\
\hline $\begin{array}{c}\text { Transaction } \\
\text { Coverage - Low }\end{array}$ & $\begin{array}{c}\text { Product } \\
\text { Oriented } \\
\text { Business Model }\end{array}$ & $\begin{array}{c}\text { Project } \\
\text { Oriented } \\
\text { Business Model }\end{array}$ \\
\hline & $\begin{array}{c}\text { Standardized } \\
\text { level of offers } \\
\text { customization }\end{array}$ & $\begin{array}{c}\text { Individualized } \\
\text { level of offers } \\
\text { customization }\end{array}$ \\
\hline
\end{tabular}

As noted by Loucks et al. [17], there is an approach that involves the classification of business models depending on the type of value for the client that they provide: i) the value of the value; ii) the value of the interaction; iii) the value of the platform. Let us consider the features of these business models. 
The value of the value: The most intense competition between companies occurs within the framework of this strategy. Companies greatly reduce the cost of the product for customers. Great opportunities for lowering prices are provided by product virtualization. In the framework of this approach, there are such business models as:

- Price transparency;

- Free/very low price;

- Reverse auction;

- Buyers association;

- Consumption-based pricing.

\section{The value of interaction.}

This approach is based on the fact that customers are offered a more convenient way to obtain a product or service. As digitalization intensifies, the value of interaction increases. This is due to the fact that now in the value chain you can select only those elements that attract the buyer and transfer them to digital devices.

The most successful digital companies are disaggregating the products of companies from different industries. They provide an opportunity for customers to select (and pay) only those products and services that are valuable to them, excluding other elements included in the chain and leading to an increase in prices.

Digitalization enables new companies to personalize their products and services and provide them at lower prices than traditional companies.

This approach complicates the activities of established companies that are accustomed to competing either through differentiation or brand. Examples of business models based on the value of interaction are:

- Empowerment of customers;

- Individualization;

- Receiving results in real time;

- Reduction of disagreements;

- Digital technology.

\section{The value of the platform.}

The value of the platform is a new form of competition, which arose precisely in the context of digital transformation. The business platform is non-linear and is determined by network effects.

Network effects are determined by Metcalfe's law, according to which the value of the network grows in proportion to the square of the number of users. These effects arise due to various forms of interaction between network participants:

- Dependence on each other;

- Equal relations with each other;

- Interconnection in the process of game models;

- The presence of feedback between the participants

Due to the existence of such forms, the overall effect of network activity exceeds the results of interaction within the framework of individual areas of its functioning. Thus, the presence of the platform allows the client to get additional value associated with connecting him to the network. For companies, such a business model is very attractive.

In the event that the platform is effective, then it has a very high degree of competitiveness. The result of such an activity is the approach when "the winner gets everything." The owners of the platform earn the bulk of the profit in individual markets. Examples of such platforms are Apple, iTunes, Facebook, and other business models. Within this framework, the following business models are distinguished:

- Crowdsourcing;

- Ecosystem;

- Communities; 
- Digital market;

- Data orchestrator.

The analysis shows that at present, companies use a variety of business models to maintain and enhance their competitiveness. For the energy companies, the problem arises of choosing the most relevant digital business model and developing a strategy for the transition from the current business model to a digital one.

\section{Approaches to transformation the activities of energy companies in the transition to a digital business model}

The choice of an acceptable digital model should be determined by the real capabilities of the company and how it wants to compete. In what directions do the leaders and organizations of the energy industry need to decide in order to move to the transformation of the business model in the direction of its digitalization? The analysis shows that, first of all, it is necessary to assess organizational competencies in the following areas, the characteristics of which are presented in Table 3 that follows.

Table 3. Directions for assessing the organizational competencies of energy companies for the transition to a digital business model

\begin{tabular}{|c|c|}
\hline $\begin{array}{c}\text { Organizational } \\
\text { competencies }\end{array}$ & Directions for assessing \\
\hline $\begin{array}{c}\text { The impact of digitalization } \\
\text { on company products } \\
\text { /services }\end{array}$ & $\begin{array}{c}\text { A service or product is provided using the Internet; } \\
\text { Whether there is an influence of companies in other industries on } \\
\text { the product / service; } \\
\text { Is there a possibility of replacing the product / service with } \\
\text { another digital product; } \\
\text { Possible financial losses on the company's products / services } \\
\text { from digitalization }\end{array}$ \\
\hline Competitiveness & $\begin{array}{l}\text { The quality and relevance of the information that the company } \\
\text { places for customers; } \\
\text { The possibility of cross-selling and organizing multi-channel } \\
\text { services for customers; } \\
\text { - The quality of the internal platform of the company; } \\
\text { The ability to connect external suppliers, partners, customers to } \\
\text { the platform }\end{array}$ \\
\hline Current business model & - $\quad$ Linear model (single transactions, omnichannel, etc.); \\
\hline Organizational effectiveness & $\begin{array}{l}\text { The possibility of multi-channel customer experience; } \\
\text { - Analytics about customers during their life cycle; } \\
\text { The possibility of expanding and developing partnerships; } \\
\text { The presence of a brand that allows you to dominate in case the } \\
\text { client needs a product / service }\end{array}$ \\
\hline $\begin{array}{l}\text { Corporate Culture and } \\
\text { Leadership }\end{array}$ & $\begin{array}{c}\text { The deep competencies of the Board of Directors and the General } \\
\text { Director in the field of digitalization; } \\
\text { The impact of the director of information technology on the } \\
\text { activities of the Board of Directors; } \\
\text { Organizational flexibility and adaptability; } \\
\text { The propensity of organizational culture to digitalization }\end{array}$ \\
\hline
\end{tabular}

The assessment will allow leaders to understand which business model is current and what level of digital culture the company has in order to begin the transformation towards a digital business model. 
Once the assessment has been completed, a vision for a new digital business model, a digital strategy and an implementation plan must be formulated. An analysis of the experience of companies that have carried out the transformation of business models shows that a digital strategy is not just measures to automate individual functions. Digital transformation must be part of the corporate strategy and requires the active involvement of the company's top management.

When developing a digital strategy, it is necessary to determine the main directions of change and the necessary resources (financial, technical, human, etc.) for the transition to a new business model. It is important to form a cross-functional team of specialists who will launch change projects. In addition, it is necessary to develop the digital skills and competencies of all employees in the company.

Many companies introduce additional levels of hierarchy for technicians: at one level, there are specialists who perform standard tasks, and at a higher level, those who perform more complex creative tasks.

For the implementation of projects related to the expansion of the list of services of energy enterprises, it is advisable to interact with technology companies and start-ups. These joint ventures enable energy companies to leverage digital skills and know-how that they lack.

\section{Conclusions}

Overall, it appears to us that the success of energy companies in the digital environment presupposes not a simple use of digital technologies to automate certain functional areas, but a change in production and management business processes, value chains, and ways of doing business.

It becomes apparent that digitalization provides energy companies and their leaders with opportunities to qualitatively change their business and increase its competitiveness through the introduction of digital business models. These models improve customer service and reduce costs through standardization and streamlining of operations.

Finally, we can conclude by stating that digital business models allow in the short term to improve the efficiency of current operating activities, and in the long term - to offer customers new customer value.

\section{References}

1. K. Shvab, N. Dehvis, Tekhnologii chetvertoy promyshlennoy revolyutsii (2018)

2. A. Ross, Industrii buduschhego (2016)

3. N. Bostrom, Iskusstvennyi intellekt. Etapy. Ugrozy. Strategii (2016)

4. Ministerstvo tsifrovogo razvitiya, svyazi i massovykh kommunikatsii RF, https://digital.gov.ru/uploaded/files/tsifrovaya-energetika16x915.pdf(2019)

5. Assotsiatsiya Tsifrovaya Energetika, https://www.digital-energy.ru/wpcontent/uploads/2020/04/strategiya-tsifrovoy-transformatsii-elektroenergetiki.pdf (2020)

6. TADVISER, https://www.tadviser.ru/index.php (2020)

7. MITSloan Management Review, Tsifrovizatsiya: Prakticheskie rekomendatsii po perevodu biznesa na tsifrovye tekhnologii (2019)

8. V. Smil, Energy Transitions: Global and National Perspectives (2017) 
9. D. Ergin, Novaya karta mira: Energeticheskie resursy, menyayuschchiisya klimat $i$ stolknovenie natsi (2021)

10. D. Ergin, V poiskakh energii: Resursnye voiny, novye tekhnologii i buduschee energetiki (2017)

11. V. Smil, Energetika: mify i real'nost' (2012)

12. V. Smil, Energika i tsivilizatsiya (2020)

13. RBK, https://trends.rbc.ru/trends/innovation/5d6796719a7947b5b36a5972 (2020)

14. A. Osterval'der, I. Pin'e, Postroenie biznes-modelei. Nastol'naya kniga stratega $i$ novatora (2012)

15. P. Vail, S. Vorner, Tsifrovaya transformatsiya biznesa: Izmenenie biznes-modeli dlya organizatsii novogo pokoleniya (2019)

16. K. Lints, G. Myuller-Stivens, A. Tsimmerman, Radikal'noe izmenenie biznes-modeli: Adaptatsiya $i$ vyzhivanie v konkurentnoi srede (2019)

17. D. Lauks, D. Makolei, E.H. Noronkha, M. Uehid, Kak pobezhdat' didzhital-novatorov ikh zhe oruzhiem (2016) 